\title{
The Chairman's Annual Report for the Year 1977-1978
}

The end of the current year will mark the completion of twentyfour years in the life of the Anglo-Byelorussian Society, as well as the beginning of the 13th session of the Annual Course of lectures on Byelorussian culture. It is encouraging to observe that despite organisational and other difficulties, the Society continues to maintain regular activities, and to enjoy the loyal support of its members and friends.

During the past session there have been six applications for membership of the Society, which will go some way to compensate for the loss through death of two longstanding supporters and members of the Society - Professor Robert Auty and Mr Arthur Fenlon. Professor Auty, who members will recall was for four years a Vice-President of the Society, first became acquainted with the Byelorussian language through meeting in Warsaw some Byelorussian students from Vilna shortly before the Second World War. Their appeal to him did not go unanswered, for in due course in London Professor Auty did much to encourage his students to turn to Byelorussian studies; it was also he who in 1965 wrote the introduction to the Journal of Byelorussian Studies. The Society owes much to him for his support, and the death of such an eminent supporter is a sad loss indeed. A number of members of the Society attended his memorial service in Oxford last month.

The financial affairs of the Society continue on a satisfactory basis, with income for the past year standing at $\$ 2,047$ and expenditure at $£ 2,055$. We are as usual very much indebted to the Byelorussian Charitable Trust for its generosity in renewing its grant to the Society, and we also gratefully acknowledge a donation from the Byelorussian Social Club in Bradford last July.

Thanks to this and other continuing support, we have this year been able to produce a further issue of the Journal for 1977 (Vol. IV, 1.) which was recently distributed. The growing list of contributors shows that the Journal is providing an increasingly necessary forum for scholars interested in Byelorussian affairs. We have to report the retirement as Editor of Mr James Dingley (University of Reading) after six years in arduous office. The Society is grateful to him for his work and support over the period of his editorship, and duly records its appreciation and thanks for the valuable contribution he has made in making the Journal a success. At the same time we extend a warm welcome to his successor Mr Peter Mayo (Sheffield University), who has been a good friend of the Society, and who in addition to his contributions to the Lecture Course, is the author of a highly esteemed Grammar of Byelorussian (1976). 
The twelfth annual Lecture Course has proved a continuing success. Meetings were held throughout the session at the Francis Skaryna Library, where hospitality and refreshments are so generously provided by friends. It was therefore with particular pleasure that we learnt of Father Alexander's elevation to the dignity of a mitred Archpriest. Many will see in this honour a well-deserved tribute to the pastoral as well as to the cultural activity of a distinguished Slavist and historian.

On 3rd November 1977 Professor McMillin addressed the Society on the subject of 'Maksim Bahdanovič and the development of Modern Byelorussian poetry'. The Hon. Secretary presented a paper on 8th December dealing with 'Sixty years of Byelorussian postage stamps, postal vignettes and labels (1918-1978)'. Father Nadson on 16th February 1978 spoke on 'The terminology relating to Byelorussia from the 17th to the 18th century', whilst Mr Peter Mayo on 16th March chose as his subject 'Byelorussian orthography from 1933 to the present day'. On 11 th May Mme Shirin Akiner gave a lecture on 'Oriental borrowings in the language of the Byelorussian Tatars'. The course ended on 8th June with a paper by Mr J. Dingley entitled 'Sixty years on: the Byelorussian National Republic in historical perspective'. Attendances varied between 14 and 26, with an average of 19 members and guests present. Questions and discussions continued over an agreeable collation served with wine.

A number of members of the Society attended the Eighth International Congress of Slavists in Zagreb (Yugoslavia) from 3rd-9th September 1978, including the Hon. Secretary. Professor McMillin and Shirin Akiner both presented papers, and Archpriest Nadson took an active part in discussions. The Congress offered an excellent opportunity to meet scholars engaged in Byelorussian studies, both from the Soviet Union and from other countries.

Finally the Society records with regret the recent death on 26th December 1978 at the age of 88 years, of Fr Jazep Hermanovič, a noted Byelorussian poet (Vincuk Advažny) and long-standing supporter of the Lecture Course. His charm and wit will be sorely missed at future meetings.

Members of the Council met ad hoc on a number of occasions to deal with the day to day business of the Society and organise its activities.

It only remains for me to add my personal word of thanks to my fellow Council members and to all the friends of the Society for helping to maintain successfully the life and activities of our organisation.

John Jolliffe

Chairman.

EDITORIAL NOTE

Professor A. B. McMillin and Vera Rich wish to make the following clarifying statement:

'In the last issue of the Journal of Byelorussian Studies the translation of Taras na Parnasie was by Vera Rich, and the accompanying introduction and notes by Arnold McMillin.' 